\title{
Policy Recommendations towards Water Sharing Geopolitics between India and Bangladesh
}

\author{
Mst. Kamrun Naher ${ }^{1 *}$, AHM Mahbubur Rahman², Md. Oly Ullah Chowdhury ${ }^{3}$ \\ ${ }^{1}$ Faculty of Social Science, Bangamata Sheikh Fojilatunnesa Mujib Science and Technology University, \\ Jamalpur-2012, Bangladesh \\ ${ }^{2}$ Assistant Professor and Chairman, Department of Social Work, Bangamata Sheikh Fajilatunnesa Mujib \\ Science \& Technology University, Jamalpur -2012, Bangladesh \\ ${ }^{3}$ Lecturer, Department of Social Work, Bangamata Sheikh Fojilatunnesa Mujib Science and Technology \\ University, Jamalpur-2012, Bangladesh.
}

*Corresponding Author: Mst. Kamrun Naher, Faculty of Social Science, Bangamata Sheikh Fojilatunnesa Mujib Science and Technology University, Jamalpur-2012, Bangladesh.

\begin{abstract}
This paper assesses the Bangladesh-India water sharing disputes which dates back to the early 1970s with India's ill-conceived construction of Farakka Barrage on the Ganges. Unfortunately, the bypassing of the international laws and unilateral diversion of water from trans-boundary Rivers has been the long-standing policy of India. Without any agreement with Bangladesh, it has embarked on constructing dams and diverting water from many trans-boundary rivers such as Teesta, Gumti, Khoowai, Dharla, Dudkumar, Monu etc. India also reportedly blocked rivers such as Muhuri, Chagalnaiya, Fulchari, Kachu and many others in Tripura flowing into Bangladesh. This caused a steady reduction in water flow. Meeting increased water demand for the fast growing population will be a great challenge for Bangladesh, while India continues its non-compromising attitudes on water sharing. Against this backdrop, water scarcity will trigger conflicts and social instability in Bangladesh and it may spill over borders and can be a threat to international peace and security. This research paper argues that the water issues need not to be a cause for tension; rather it can be a catalyst for cooperation between India and Bangladesh. Such cooperation is the only remedy to avert future water conflict obtains collective rights and ensure sustainable ecosystem for both of the country.
\end{abstract}

Key Words: Bangladesh, India, water sharing, transboundary crisis, policy direction

\section{INTRODUCTION}

The term used to the politics related to water refers to the relationship affected by the availability and management of water and its related resources. It is also termed as hydro-politics over the world. The convenience of drinking water is shriveling around the world which is affecting the ecosystem and the economic development of the world especially to the developing counties like Bangladesh. It is creating not only interstate issues but also intrastate crisis within the affected counties. Thriving deficit of water in affected countries is creating a thirst of controlling water and water related resources which is provoking tensions that is ultimately teeming conflict. Around the world there are almost 215 rivers and 300 water basins are being shared by two or more counties. By these tensions are appearing regarding predominance, supply of water, apportionment, possession and usage. It is being assumed that the control of water resources defines the survival of states in the system of power politics regarding water.

Conflicts between India and Bangladesh regarding water date back to the early 1970s which was started by the issue of sharing the water of Ganges and Teesta. As a lower riparian country Bangladesh shares almost 54 rivers with India on which Bangladesh has no or limited control over them. Divergence of water from these shared rivers has been a long standing policy of India for this they constructed dams on many shared rivers without the consent of Bangladesh.

Though there exists India-Bangladesh Joint River Commission (JRC) for settling the issues regarding these tarns-boundary rivers, India did not come to any kind of agreement regarding the divergence of water from these shared rivers as these rivers exist within the territory of India. In 1975 India constructed its first dam over these trans-boundary rivers named Farakka Barrage for the divergence 
of water of Ganges to enhance the navigability of Calcutta Port in the dry season. For this the supply of fresh water from the Ganges Basin shockingly decreased in the South-West part of Bangladesh which affected agriculture, fisheries, forestry, industries, depletion of ground water, salinity to the coastal areas which caused a severe damage to the overall economic development of that area.

It has become one of the crucial challenges for Bangladesh to meet the enraged demand of water of the fast growing population. It is not very tough to assume that tensions over water scarcity can be a good source of motivation of conflict which may spill over borders of the two countries and can be propulsion to the regional conflict.

\section{LITERATURE REVIEW}

There is a growing body of literature on the effect of water disputes on regional peace and stability. Gleick's scholarly works have shown that climate-induced water scarcity can put enormous pressures on the international community, and that such scarcity can often lead to regional and international conflicts. A study by Jansky and Murakami (2005) shows that river diversions often have adverse effects on the environment and such effect can be mitigated by joint scientific study by common river basin countries. Others have looked into the policy options in resolving water disputes. For instance, McGregor's study on Indo-Bangladesh water dispute explores the unilateral, bilateral, and multilateral options in resolving such disputes. Media reports often indicate that river disputes present enormous challenges in bilateral relations. Such disputes can be dominated by either an upstream country like China or a downstream country like Egypt. South Asia, home to roughly one fourth of world's 6 billion people, is plagued by a number longstanding water disputes. Hence, considerable attention has been paid to analyzing water disputes in South Asia. Mahfuz Ullah's edited volume titled Water Disputes in South Asia: Threats to Security (2005) shows the delicate nature of inter-state conflict over common rivers. The works of Abbas (1987), Nishat (1996), and Swain (1993) address the dominant water conflict in South Asia - the Ganges dispute. A quick scanning of major newspapers in Bangladesh indicates that Teesta water sharing and Tipaimukh dam debates now dominate the IndoBangla relations

Iram Khalid in his research book named Bangladesh Water Concern focused on the water issues between India and Bangladesh. He focused on the Eastern Himalayan Region (EHR) with special references to Bangladesh-India water dispute. The paper highlighted the factors which have serious concerns that after long term comprehensive bilateral negotiations are still unresolved. He explained problems that are placed in the language of agreements signed and further to understand those prospects for understanding future in context of the prevailing circumstances.

Peace Research Institute Oslo (PRIO), annual report 2013 argues that as an agrarian and riverine country, Bangladesh is dependent on river water for human consumption, crop irrigation, fisheries, transportation and conservation of biodiversity. In parts of GBM Basin there are disturbing signs of decreasing dry season river flows with serious consequences for agriculture and ground water replenishment. It also reported that the problem is further exacerbated by water pollution, water politics and inefficient water management and Unitarian attitude of India in sharing river water.

Institute for Defense Studies and Analyses (IDSA) report 2010 summarized that, water is a fundamental human need and critical national asset. India is facing a serious water resources problem as it is expected to become water stressed by 2025 and water scarce by 2050 . The IDSA report raises fundamental question about the forces driving water demand and the political dynamics of riparian relations both in terms of hindrances and opportunities. The report argued that management of water does not take place in a vacuum rather in a complex political and economic framework. The implementation of river policies, linking rivers, constructing dams are undertaken within a political context.

Muhamad Mizanur Rahaman in his research named the Ganges Water Conflict: A comparative analysis of 1977 agreement and 1996 treaty, examined these two treaties between Bangladesh and India for sharing water of Ganges River and augmenting flow during lean season. Then he compared these two treaties. Finally he recommended some provisions that would likely to contribute toward resolving the conflict and achieve an integrated water resource management.

Md. Shariful Islam in his book named Bangladesh-India Water Sharing Disputes: Possible Policy Responses assessed the Bangladesh-India Water sharing disputes with historical background. He 
argued that as a lower riparian country Bangladesh has no control over the rivers. India takes every decision about the rivers without consulting with Bangladesh. He also argued that decreased supply of water adversely effect on the South-West part of Bangladesh especially agriculture, navigation, irrigation, fisheries, forestry, industry, salinity, ground water depletion, coastal erosion, sedimentation have been adversely affected.

\section{Methodology}

This is a qualitative study that relies on secondary information. Books, reports, published research studies, newspapers, articles, seminar and conference papers, national and international journal publications, periodicals, documents available on the internet, and government plans and programs are examples of secondary sources. The depiction and synthesis of the gathered data was done with the paper's broad perspective in mind.

\subsection{Theoretical Framework}

As my hypothesis is that India's unitary decision on river water sharing is mostly to blame for the India-Bangladesh water sharing issue, I will base the framework of my research on this premise. Because water sharing is a bilateral issue, decisions should be made on a bilateral basis as well. The most desirable answer to this situation is cooperation. If India does not work with Bangladesh on any policy, agreement, treaty, or decision, the situation will persist. India, as an upper riparian country, should be the first to extend a hand of cooperation. They must reach an agreement while taking in mind Bangladesh's water dilemma. Bangladesh should also work with India to tackle the problem in any way possible because water is a vital resource. I'm going to use game theory to come up with a viable solution to the water situation. Especially the cooperative game theory, because it states that the participants in a competition can communicate and work together to reach any binding conclusion that will help them keep their promises. The best way to solve this issue is to talk and work together.

\section{ANALYSIS}

Water may be a good source of conflict when it comes to three specific contents. They are fresh water shortage, unequal access to water, and a lack of control over water resources as a result. Excessive industrialization causes climate change, which leads to global warming. The melting of the ice caps is due to global warming, which has raised concerns about world security. The second concern is unequal water access, which is clearly linked to riparian countries like Israel, Jordan, and Palestine, which are fully dependent on the Jordan River, which Israel controls, and Turkey and Syria, which rely on the Euphrates River, which Turkey controls.

Bangladesh is likewise reliant on water from the Indian-controlled Ganges River. These are a few examples of riparian counties where water access is unequal. A water conflict arises when multinational companies (MNCs) control water resources and refuse to make them available to the poor, notably in third-world low-income countries.

According to available data, three major water-sharing problems exist between India and Bangladesh, all of which have a negative impact on their relationship. Between India and Bangladesh, there is a water dispute over the Ganges, a water dispute over Tipaimukh, and a water conflict over the Teesta. The graph depicts India's overarching stance toward Bangladesh over time. Furthermore, as a lower riparian country, the need for water has long been disregarded.

\subsection{The Ganges Dispute}

The Ganges is one of the world's largest international rivers, with a flooding area of 46,300 sq km, roughly a third of Bangladesh. Before entering Bangladesh, the Ganges flows from the Indian states of Uttar Pradesh, Bihar, and West Bengal, where it originates from Himalayan glaciers. Bangladesh is heavily reliant on the Ganges as a lower riparian country. The Ganges Water Dispute is at the center of many bilateral concerns. The Ganges is the lens through which most Bangladeshis view India. After the construction of the Farakka Barrage, a controversy arose.

In 1972, following Bangladesh's independence, a joint river commission was established to promote equitable trans-boundary river sharing. In 1975, India and Bangladesh struck an agreement for the propulsion of a 41-day experimental operation of the Farakka Barrage. However, in 1976 and 1977, India broke international law by withdrawing water from the Ganges. Bangladesh brought the issue to 
the attention of the UN, the NAM, and the OIC. However, they were unable to find a viable solution to the situation. In 1977, India and Bangladesh negotiated a five-year water-sharing agreement, which was then extended in two phases until 1988. Later, India refused to agree to any more treaty extensions and unilaterally withdrew water.

After the Awami League came to power in Bangladesh in 1996, they signed the Ganges Accord 1996, a contract regarding Ganges water sharing. Bangladesh was promised 35,000 cubic meters of water during the dry season as part of the agreement, and they also pledged to cooperate and share similar aims. Now one must need to understand why the matter is so significant to Bangladesh that it has been brought to the attention of the international community. The shortage of water from the Ganges resulted in increasing salinity in the Padma Basin, which disrupted the navigational pattern and harmed Bangladeshi agriculture.

The Ganges dispute can be used to learn a variety of lessons in this way. First, India's unilateral withdrawal of water from the Ganges has had a significant impact on Bangladesh; second, India's insistence on a bilateral dispute settlement procedure has trumped Bangladesh's appeal for a multilateral approach. Finally, many people have been annoyed by India's regional bully-like approach toward Bangladesh, similar to China's hydro-hegemonic attitude toward India and other South Asian countries.

Following the agreement, the settlement agreement quickly became insufficient due to a variety of factors such as:

1. Extreme drought season having limited preparation made the Accord ineffective.

2. Lack of a strong crisis management plan made the Accord weak.

3. India planned for more dams which became a threat to the Accord.

4. India embarked on a new initiative called the Indian River Link Project, which is largely aimed at the Ganges River. India planned to build a dam similar to the one on the Ganges on the other 53 rivers that flow into Bangladesh via India. Because $80 \%$ of Bangladeshi farmers rely on river water for agriculture, the connection project has become a security risk. As the water layer will become very low they can't produce anything in the drought season. It is also another crucial factor for the Accord of being inadequate.

5. Though the Authority stated that the dams will only be used to recover extra water so that it may be used in times of need and that it will have no detrimental impact on Bangladesh, the Bangladeshis' previous experience of being violated from the higher riparian state was not sufficient. As a result, they were not prepared to be the victim once more.

\subsection{The Tipaimukh Dispute}

On the border of Kolashib-Mizoram and Churachandpur-Monipur, the Indian government proposes to build Tipaimukh, a multipurpose dam that will generate 1500 megawatts of electricity and aid in the control of fold to the suffering areas. Despite their repeated assurances to Bangladesh that they would not damage any part of the country, the signing of a treaty with the government of Monipur and National Power Cooperation of India Limited (NPCIL) without Bangladesh's authorization came as a surprise.

Bangladeshi intelligentsia had conflicting feelings about the project plan. Many think that having access to the Tipaimukh Hydropower Plant would benefit Bangladesh. Others argue that diverting water from Tipaimukh will create flooding in Sylhet, Bangladesh's lower reaches. Skeptics, on the other hand, dismissed the hypothesis of hydropower and additional water, claiming that India had a history of misleading Bangladeshi citizens.

As a result, any water diversion may have a negative impact on Bangladesh's lower riparian Sylhet and Moulovibazar districts; it may induce flash floods in the area, causing harm to the area's boro production. The proposed Tipaimukh dam, which is located in a seismically active area of Bangladesh and is at risk of a large earthquake, will cause a massive calamity in that part of the country. In response to the criticism, India and Bangladesh decided to collaborate on a feasibility assessment for the proposed dam. 


\subsection{The Teesta Dispute}

Teesta is a big international river that originates in Sikkim, India and flows through Bangladesh for 124 kilometers and India for 97 kilometers. The Teesta's water is vital to the agricultural and navigational processes in Bangladesh's northern and northeastern regions. India constructs an upstream barrage at Gazaldoba, while Bangladesh constructs a downstream barrage to ensure irrigation water and control flood. The Teesta issue has intensified as Bangladesh requests 55 percent of the river's water at Gazaldoba Point, while India refuses to oblige. During the Indian Prime Minister's visit to Bangladesh in September 2015, a Teesta Treaty was ready to be signed, but it was thwarted at the last minute by West Bengal Chief Minister Mamata Banerjee's opposition. Mamata stance was to give 25 percent of Teesta water to the downstream Bangladesh.

Teesta Barrage's construction was finished in 1998. The Teesta water dispute has harmed Bangladesh since a lack of water during the dry season rendered it utterly unusable. The JRC has never been able to give the Teesta water conflict the attention it deserves. Unlike the other issues, the Teesta water dispute has not changed.

As a result, there are various lessons to be learned from the conflict. To begin with, unlike other crises such as the Ganges conflict or the Tipaimukh dispute, the Teesta calamity has a severe influence on regional peace and unity. Second, as a lower riparian state, Bangladesh is completely reliant on India's condescension on the matter of sharing water from the common rivers. Third, and most significantly, until and unless the state's chief minister clears the way for an agreement to be signed, any bilateral decision made at a JRC meeting is unlikely to yield any real results.

\section{FINDINGS}

The important research findings are summarized here:

a)If adequate steps are not done quickly, fresh water scarcity may one day lead to a Third World War, as demand for fresh water is increasing while supply is dramatically dropping. Water security is a possible source of conflict because it directly affects human security. Concerns that climate change would deplete water resources and exacerbate water conflicts would be growing. According to the report, Bangladesh's main issue in securing national security will be water insecurity, as the country's vulnerabilities stem from both domestic and external sources. Bangladesh's suffering will be exacerbated in the near future as India and China plan to construct 200 large and small dams on the Himalayan Rivers Yangtze, Brahmaputra, and Ganges to meet their growing demands. In this setting, conflicts between nations are quite likely, as the scarcity of fresh water resources worsens dramatically. Furthermore, India's unwillingness to compromise on water sharing could lead to violence between Bangladesh and India.

b)Water scarcity is also a major worry in salinity-affected areas. Stagnant salt water on the surface of the soil frequently seeps into ground water stones, polluting fresh water and rendering it unfit for irrigation or consumption. In regions where tube wells are placed at a low altitude and are susceptible to pollution by salt water, tensions can arise between populations. Furthermore, women who are responsible for providing water for their families suffer greatly as a result of limited access to water. It has the potential to exacerbate female insecurity and sexual aggression.

c)Environmental concerns have the potential to have a negative impact on Bangladesh's domestic politics. Certain pressure groups, such as extreme Muslim groups, may be able to utilize an environmental issue like water sharing as a political issue, particularly against India. This has the potential to disrupt internal power dynamics and lead to political instability. The study also shows that the impact of fresh water scarcity will hasten Bangladesh's economic instability, as water is required for irrigation, hydroelectricity, and other purposes.

d)Diseases will become more prevalent as the quantity of fresh water decreases. Following flooding, contaminated water can exacerbate outbreaks of skin disorders, eye infections, cholera, diarrhea, dysentery, and fever. Low-lying communities that rely on tube wells for water are particularly vulnerable.

\section{Policy Recommendations}

From a long-term viewpoint, water shortage must be considered a severe issue. It may appear less harsh now as a gradual process, but we must consider the next generation and whether they will have 
access to fresh water to meet their needs. Some policy ideas for both the Bangladeshi and Indian governments to address the issue of water scarcity are offered below:

a) Advancing Regional Collaboration and Integrated Water Resource Management: Because the water management of GBM basin of transboundary Rivers involves multiple countries, including Bangladesh, India, China, Nepal, and Bhutan, integrated water resource management is critical. When it comes to regional and global water sharing challenges, there is no other option but cooperation. For Bangladesh, regional collaboration among co-riparian countries is critical. Due to a water-sharing conflict between India and Pakistan, it needs to form alliances and boost lobbying efforts with Nepal, Bhutan, and Pakistan. Many experts believe that resolving the water conflict with India on a bilateral basis is impossible, and that we must instead take the matter to a global organization such as the United Nations.

"We have waited 36 years and failed to address the problem bilaterally," former Joint Secretary A.B.M.S. Zahur noted in this regard. It looks that we have no choice except to take the subject to the United Nations in order to raise the world's attention to our suffering. Justice, not favor or compassion, is what we want."

According to Shamsher Chowdhury, "The water-sharing disagreement dates back three decades, and bilateral agreements are rarely used to resolve such disputes. The ruling establishment must now internationalize the problem including the United Nations and the International Court of Justice." Air Commodore (retired) Ishfaq Ilahi said, "There is a risk of future war and tensions in the region unless the riparian countries band together to ensure optimal water utilization."

M. Rashed Chowdhury claimed, "Through regional cooperation on water management and conservation, as well as the development of comparative projects at the regional level in terms of exchange of best practices and knowledge, capacity building, and the transfer of eco-friendly technologies, SAARC can play an important role in reducing vulnerabilities to future water-related disasters."

Finally, there are a number of actions that must be performed in order to promote regional cooperation. In this context, the Abu Dhabi Dialogue (which includes Bangladesh, India, Nepal, Bhutan, Pakistan, Afghanistan, and China) can be viewed as one path for facilitating regional water management cooperation in the Himalayan region.

b) Taking Care of Teesta Water: As there is unfairness in the current Teesta water sharing arrangement, India must establish equity and fairness not only in dealing with Teesta but also other common rivers. "India apparently has access to 32,000 cusecs during the lean season for 8 million people, whereas Bangladesh makes due with just 5,000 cusecs for 20 million people," says Praful Bidwai."

Bangladesh relies on Teesta water for agriculture during the dry season, which begins in September and lasts until March. As a result, a deal on Teesta water sharing with India is critical. During the dry season, the Teesta's flow drops to between 5000 and 6000 cusecs, while Bangladesh and India's water demands are 8000 and 21000 cusecs, respectively. As a result, it is a problem that must be handled with caution. It can serve as a platform for future cooperation, particularly in terms of sharing the water of the Dudkumar, Manu, Khowai, Gumti, and Muhuri rivers in order to fulfill future water demands.

Furthermore, both countries must address their true water needs and develop proper strategies that are backed up by substantial funding to meet future water scarcity. Finally, it has been claimed that we rely heavily on Indian statistics in our bilateral meetings with India. As a result, decisions made at such meetings are usually in India's favor.

India is Bangladesh's largest and most important neighbor. Both countries have a large land border, and researchers and policymakers in both countries consider that Bangladesh's relations with India are strategically and physically essential. While negotiating with India, Bangladesh must take advantage of its geostrategic importance. As a result, when it comes to negotiating, Bangladesh must keep in mind that the techniques of diplomacy require us to gain something in exchange for something, and we must prioritize our national interests. Through effective diplomacy, Bangladesh can achieve reasonable and equitable water distribution. 
When it comes to supply, huge dam projects aren't the sole option for India; there are other options. Watershed development and local rainwater harvesting are also part of the supply side response to demand. It may be possible to avoid a crisis by combining these two factors: on the demand side, the practice of utmost economy and efficiency in water use, as well as reasonable conservation, and on the supply side, efforts to augment the availability of usable water through extensive resources to local water harvesting.

Finally, Bangladesh and India must accept and comprehend each other's legitimate rights and requirements. Mutual trust in pledges, commitment implementation, and the avoidance of ambiguous statements and behaviors are also essential for settling disagreements. In the future, both sides should maintain close contact with neighboring states and mitigate their disagreements in order to maintain a positive neighborly relationship.

\section{CONCLUSiON}

The nature of India-Bangladesh water disputes is examined in this research. According to the report, Bangladesh and India have a long list of misconceptions and mistrust. India, as a major actor, is reaping the full benefits of being an upstream state, as international law permits an upstream state to utilise water flowing through its borders. This is why all international venues, including the United Nations, have emphasized the importance of resolving the matter bilaterally. This study claims that Bangladesh and India have three options for settling their water disputes: doing nothing, unilateral action, or coordinated action. The last choice, according to this paper, is the optimal method. It necessitates the employment of a collaborative scientific study, bilateral and multilateral agreements, and suitable measures to address the effects of water-sharing issues.

\section{REFERENCES}

[1] Bhushan, B., \& Ahmed, J. An Analytical Review of Media Reports: Context of Trans-boundary Aspects of the Teesta River. International Union for Conservation of Nature, Ecosystems for 53 Life: A BangladeshIndia Initiative, 2014.

[2] Islam, M. F. Identification of the Problem. In M. F. Islam, Water Use and Poverty Reduction (pp. 1-12), 2016

[3] Islam, M. F. The Teesta River and Its Basin Area. In Water Use and Poverty Reduction. New Frontiers in Regional Science: Asian Perspectives, Vol. 8, (pp. 13-43), 2016.

[4] Gleick, Peter H. Effects of Climate Change on Shared Fresh Water Resources. In Confronting Climate Change: Risks, Implications Responses, edited by I.M. Mintzer. Cambridge: Cambridge University Press, 1992.

[5] McGregor, Joel. (2010). The Internationalization of Disputes over Water: The Case of Bangladesh and India. Australasian Political Studies Association Conference, ANU, Canberra, 3rd-6th October 2000.

[6] Chellaney, Brahma. Water: Asia's New Battleground. Washington, D.C.: Georgetown University Press, 2011.

[7] Rizvi, Gowher. Tipaimukh: A Plea for Rational and Scientific Discussion, December 13, 2011.

[8] Khalid, Iram.” Bangladesh Water Concern”, South Asian Studies - A research Journal of South Asia, Vol25. No- 01, PP (73-87), January-June 2010.

[9] Peace Research Institute Oslo (PRIO), Report, "Water Scarcity in Bangladesh: Transboundary Rivers, Conflict and Cooperation", Norway, 2013.

[10] "Water Security for India: The External Dynamics", Published by Institute for Defense Studies and Analysis (IDSA), New Delhi, India, 2010.

[11] Rahaman, Muhamad Mizanur. "The Ganges Water Conflict: a Comparative Analysis of 1977 agreement and 1996 Treaty", International Water Law Project, 2006.

[12] Islam, Md. Shariful. "Bangladesh-India Water Sharing Disputes: Possible Policy Responses", University Press Limited, Bangladesh, 2012.

[13] Weinthal, E., Zawahri, N., \& Sowers, J. Securitizing water, climate, and migration in Israel, Jordan, and Syria. International Environmental Agreements: Politics, Law and Economics, 15(3), 293-307, 2015.

[14] Akter, M. Conceptualizing environmental governance on the GBM basin. Bandung: Journal of the Global South, 2(1), 1, 2016.

[15] Abbas, B.M. The Ganges Water Dispute. Dhaka, Bangladesh: University Press Limited, 1982.

[16] Crow, B., Lindquist, A., \& Wilson, D. Sharing the Ganges: The politics and technology of river development. New Delhi: Sage Publications in association with the Book Review Literary Trust, New Delhi, 1995. 
[17] Huda, M., S. Can robust bilateral cooperation on common rivers between Bangladesh and India enhance multilateral cooperation on water security in South Asia? Strategic Analysis, 37:3, 305-309, 2013.

[18] Moorthy, N. S. SAARC in coma, China throws another challenging regional initiative. Observer Research Foundation, July 10, 2018.

[19] Roluahpuia. Hydro-nation, Discourse and Discontent in Northeast India: The Case of Tipaimukh Dam, Manipur. Society and Culture in South Asia, 4(2), 255, 2018.

[20] Woodhouse, M., \& Zeitoun, M. Hydro-hegemony and international water law: grappling with the gaps of power and law. Water Policy, 10, 103-119, 2008.

[21] M. Asaduzzaman and Md. Moshiur Rahman , Impacts of Tipaimukh Dam on the Down-stream Region in Bangladesh: A Study on Probable EIA, Journal of Science Foundation, January, Vol. 13, No.1, 2015.

[22] Anuttama Banerji. India Must Settle the Teesta River Dispute With Bangladesh for Lasting Gains, the Diplomat, 09 April 2021.

[23] Baishali Mukherjee and Ujwal Deep Saha. Teesta Barrage Project - A Brief Review of Unattained Goals and Associated Changes, International Journal of Science and Research (IJSR), 2013.

[24] R. Afroz, A. Rahman, "Transboundary River Water for Ganges and Teesta Rivers in Bangladesh: An Assessment”, Global Science and Technology Journal, I (1), pp. 100-111, July, 2013.

[25] The Daily Star, June 28, 2010.

[26] A. B. M. S. Zahur, "Our dying river", The Daily Star, April 02, 2010.

[27] Chowdhury, M. S. Reducing vulnerability to water-related disasters, SAARC can play an important role, The Daily Star, May 8, 2010.

[28] Ishfaq Ilahi Choudhury, "National security: Bangladesh perspective", The Daily Star, March 6, 2010.

[29] Dr. Md Rashed Chowdhury, "Reducing vulnerability to water-related disasters, SAARC can play an important role", The Daily Star, May 8, 2010.

[30] Dr. M.A. Quassem, "Regional cooperation in water management”, The Daily Star, January 10, 2010.

[31] Praful Bidwal, "Missing a historic chance in Bangladesh", The Daily Star, September 21, 2011.

[32] "Editorial", The Daily Star, January 12, 2010.

\section{AUTHORS' BIOGRAPHY}

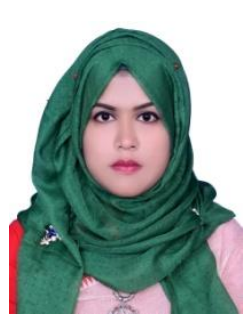

Mst Kamrun Naher, received her Bachelor of Social Science (BSS) and Master of Social Science (MSS) Degree from the Department of Peace and Conflict Studies, Faculty of Social Sciences, University of Dhaka, Bangladesh. She is currently serving as Lecturer of Bangladesh Studies, Faculty of Social Science, Bangamata Sheikh FojilatunnesaMujib Science and Technology University, Jamalpur-2012, Bangladesh. She has a keen interest in global politics, security, peace issues, electoral process and peace and conflict transformation.

Dr. A.H.M Mahbubur Rahman, was born on $1^{\text {st }}$ February 1974 in Jamalpur लिख District, Bangladesh. He obtained his PhD degree from Jahangir Nagar University, Master and Bachelor degree in Social Work from Rajshahi University, Bangladesh. He has extensive specialization in Social Work theory, practices and research methods. He teaches a number of courses of Social Work to undergraduate and graduate level students. He also supervises field work activities conducted by the graduate level social work students. He has also published some books and articles. $\mathrm{He}$ regularly writes columns and essays on contemporary issues in the daily newspaper published from Bangladesh. He is involved in different social and cultural organizations. Currently he is an Assistant Professor and Chairman in the Department of Social Work, Bangamata Sheikh Fojilatunnesa Mujib Science and Technology University, Jamalpur.

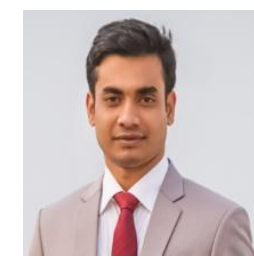

Md. Oly Ullah Chowdhury, is currently serving as a lecturer of the Dept. of Social Work at Bangamata Sheikh Fojilatunnesa Mujib Science and Technology University, Jamalpur, Bangladesh. He was also a faculty of Northern University Bangladesh. He has teaching experience of more than 5 years in the areas of Sociology and Social Work. He received his Bachelor of Social Science (BSS) and Master of Social Science (MSS) Degree in Social Work at the University of Dhaka. He has contributed a good number of research papers in different national and international journals. His research specialty and interests lie in the fields of Social Development, Global Politics \& International Relations, greening consumption and disaster management, renewable alternative 
Policy Recommendations towards Water Sharing Geopolitics between India and Bangladesh

energy, and energy security for sustainable development. $\mathrm{He}$ can be reached at olyullah@bsfmstu.ac.bd.

Citation: Mst. Kamrun Naher, et.al. "Policy Recommendations towards Water Sharing Geopolitics between India and Bangladesh" International Journal of Humanities Social Sciences and Education (IJHSSE), vol 8, no. 7, 2021, pp. 77-85. doi: https://doi.org/10.20431/2349-0381.0807009.

Copyright: (1) 2021 Authors. This is an open-access article distributed under the terms of the Creative Commons Attribution License, which permits unrestricted use, distribution, and reproduction in any medium, provided the original author and source are credited. 